\title{
Turning the Endangered Species Act
}

\section{Inside Out?}

Rancho Viejo, LLC v. Norton, 323 F.3d 1062 (D.C. Cir. 2003); GDF Realty Investments, Ltd. v. Norton, 326 F.3d 622 (5th Cir. 2003).

Within a week, both the Fifth and D.C. Circuits upheld the takings prohibitions of the Endangered Species Act (ESA) of 1973, ${ }^{1}$ as applied to species found only in single states, against Commerce Clause challenges. ${ }^{2}$ Both cases reach the same result, but the legal analysis used to get there could hardly be more different. In GDF Realty, the Fifth Circuit found the requisite "substantial impact" on commerce by treating the species themselves as commodities and aggregating the economic impact of all endangered species "takings." The D.C. Circuit, by contrast, held in Rancho Viejo that the true object of ESA regulation is not endangered species, but the commercial development that threatens them, which plainly falls within Congress's powers to regulate under the Commerce Clause. The two courts saved the threatened arroyo toads ${ }^{3}$ and subterranean invertebrates, ${ }^{4}$ but they read the Endangered Species Act as if it were two different statutes.

This curious divergence can only be understood in light of the unsettled state of Commerce Clause jurisprudence following United States v. Lopez ${ }^{5}$ and United States v. Morrison. ${ }^{6}$ Those two decisions upended fifty years of conventional wisdom about the limits on Congress's power under the Commerce Clause-namely, that there were effectively none ${ }^{7}$-and left lower courts with an uncertain new framework to apply. Of the two cases

1. 16 U.S.C. $\S \S 1531-1544(2000)$.

2. Rancho Viejo, LLC v. Norton, 323 F.3d 1062 (D.C. Cir. 2003); GDF Realty Invs., Ltd. v. Norton, 326 F.3d 622 (5th Cir. 2003).

3. The toads live in scattered populations within California and northwestern Mexico. See Rancho Viejo, 323 F.3d at 1065.

4. The six threatened species, all found only in Texas, are insects and arachnids, most of them eyeless, and all less than a centimeter in length. See GDF Realty, 326 F.3d at 625 . The GDF Realty court referred to them collectively as the "Cave Species." See id.

5. 514 U.S. 549 (1995).

6. 529 U.S. $598(2000)$.

7. Deborah Merritt memorably characterized the pre-Lopez Commerce Clause as "an intellectual joke." Deborah Jones Merritt, Commerce!, 94 MICH. L. REV. 674, 691 (1995). 
considered here, Rancho Viejo represents the abler attempt to square the ESA with the new Commerce Clause doctrine, because its analysis is more objective than GDF Realty's and more clearly satisfies the strictures of Lopez and Morrison. But like GDF Realty, Rancho Viejo must present the ESA's impact on commerce, which is peripheral in the statutory design, as the Act's core object-must turn the ESA "inside out," so to speak-in order to justify it under the Commerce Clause. This cramped conception of the statute does not convincingly justify all of its applications. The shortcomings of Rancho Viejo do not represent sloppiness on the part of the D.C. Circuit, however. Instead, they reflect the failure of the Lopez and Morrison framework to meet the Supreme Court's stated aspiration to distinguish "between what is truly national and what is truly local."8

The story starts with Lopez and Morrison. In 1995, the Lopez Court invalidated a federal statute on Commerce Clause grounds for the first time in over fifty years. The Court gave four reasons for flunking the Gun-Free School Zones Act of $1990:^{9}$ The activity it regulated-gun possessionwas not economic activity, the statute lacked a jurisdictional element, there were no legislative findings regarding interstate commerce effects, and the impact of the regulated activity on interstate commerce was not substantial. The opinion failed, however, to explain how these four factors were weighted and which were decisive. ${ }^{10}$ Morrison, which struck down part of the Violence Against Women Act of 1994 five years later, ${ }^{11}$ only muddied the waters further. Chief Justice Rehnquist's opinion repeated but did not clarify the factors from Lopez and discounted the detailed congressional findings that gender-motivated violence impairs interstate commerce. ${ }^{12}$ Lopez and Morrison thus not only circumscribed the scope of Congress's lawmaking authority, but also blurred its borders.

The Endangered Species Act was one of the many statutes left vulnerable to constitutional challenge under the new Commerce Clause jurisprudence. First enacted in 1973, the ESA "represented the most comprehensive legislation for the preservation of endangered species ever enacted by any nation." 13 The ESA was equipped with two powerful

8. Morrison, 529 U.S. at 617-18; Lopez, 514 U.S. at 567-68.

9. 18 U.S.C. $\S 922(q)(2000)$.

10. See Brannon P. Denning \& Glenn H. Reynolds, Rulings and Resistance: The New Commerce Clause Jurisprudence Encounters the Lower Courts, 55 ARK. L. REV. 1253, 1258 (2003).

11. 42 U.S.C. $\S 13,981$.

12. See Morrison, 529 U.S. at 614.

13. Tenn. Valley Auth. v. Hill, 437 U.S. 153, 180 (1978). 
provisions: section $7,{ }^{14}$ which bars federal agencies from harming a species listed as endangered by the Secretary of the Interior; and section $9,{ }^{15}$ which prohibits the taking of endangered species. ${ }^{16}$ The ESA represented a national solution to a national problem. ${ }^{17}$ On its face, though, the Act seemed to have no more connection to interstate commerce than the statutes struck down in Lopez and Morrison, and some commentators feared for its survival under the new Commerce Clause jurisprudence. ${ }^{18}$

\section{II}

The Fifth and D.C. Circuits both struggled to justify the Endangered Species Act within the Lopez and Morrison framework. The Fifth Circuit looked hard for a commercial angle to the ESA and found one in the endangered species themselves. Judge Barksdale asserted that the "ESA's protection of species is economic in nature," commercial value of endangered species' genetic resources and the opportunity for renewed trade in regenerated species as examples of the economic effects of species preservation. ${ }^{20}$ Though he acknowledged that the species in question have no commercial value at present, he stated that their protection is essential to the ESA's larger regulatory program. ${ }^{21} \mathrm{He}$ concluded that because the aggregated takings regulated by the Act substantially affect interstate commerce, the Act is a permissible exercise of Congress's power. ${ }^{22}$

14. 16 U.S.C. $\S 1536$.

15. Id. $\S 1538$.

16. What exactly it means to "take" a species has itself been the subject of debate, and it is a question that bears on the Commerce Clause issue, as is shown below. See infra notes 37-38 and accompanying text. The statute itself defines "take" to mean "to harass, harm, pursue, hunt, shoot, wound, kill, trap, capture, or collect, or to attempt to engage in any such conduct." Id. $\S 1532(19)$. In 1975, the Interior Department issued a regulation interpreting "harm" to include in certain circumstances habitat modification and degradation, 50 C.F.R. $\S 17.3$ (2003), and the Supreme Court upheld this interpretation as within the Secretary's discretion in Babbitt v. Sweet Home Chapter of Communities for a Great Oregon, 515 U.S. 687 (1995).

17. See Jamie Y. Tanabe, Comment, The Commerce Clause Pendulum: Will Federal Environmental Law Survive in the Post-SWANCC Epoch of "New Federalism"?, 31 ENVTL. L. 1051,1055 (2001) (noting that federal environmental regulation emerged in response to the states' inability to protect natural resources and address transboundary problems effectively).

18. See, e.g., Maya R. Moiseyev, Solid Waste Agency of Northern Cook County v. United States Army Corps of Engineers: The Clean Water Act Bypasses a Commerce Clause Challenge, but Can the Endangered Species Act?, 7 HASTINGS W.-NW. J. ENVTL. L. \& POL'Y 191, 193 (2001).

19. GDF Realty Invs., Ltd. v. Norton, 326 F.3d 622, 639 (5th Cir. 2003).

20. See id. at 632,639 .

21. Id. at $640-41$.

22. In insisting on characterizing the ESA as economic regulation, the GDF Realty court seemed to be responding to a brief passage in Lopez:

[The challenged provision of the Gun-Free School Zones Act] is not an essential part of a larger regulation of economic activity, in which the regulatory scheme could be undercut unless the intrastate activity were regulated. It cannot, therefore, be sustained 
The D.C. Circuit in Rancho Viejo took a very different approach. ${ }^{23}$ The court posited as the object of the ESA the 280-home residential development it blocked, not the threatened species it protected. In Judge Garland's phrase, "the ESA regulates takings, not toads." 24 The court distinguished the situation from Lopez and Morrison, in which "'neither the actors nor their conduct ha[d] a commercial character, and neither the purposes nor the design of the statute ha[d] an evident commercial nexus." "25 Not only was the affected activity here clearly commercial, but the court also argued that the design of the statute more generally related to commerce, as Congress had contemplated protecting endangered species by regulating the development of land. ${ }^{26}$

Having justified the ESA as a regulation of commercial development, the court went on to suggest that the mantle of constitutionality extends also to cover the statute's prohibition of noncommercial takings (for example, by a hiker in the woods). Quoting Lopez, the court asserted that "where a general regulatory statute bears a substantial relation to commerce, the de minimis character of individual instances arising under that statute is of no consequence." 27 But as this question was not before the court, Judge Garland declined to answer it conclusively. ${ }^{28}$ Chief Judge Ginsburg was unwilling to go even this far, and wrote separately in a concurrence that the ESA can reach only those takings that substantially affect interstate commerce. $^{29}$

under our cases upholding regulations of activities that arise out of or are connected with a commercial transaction, which viewed in the aggregate, substantially affects interstate commerce.

United States v. Lopez, 514 U.S. 549, 561 (1995), discussed in GDF Realty, 326 F.3d at 630. The court evidently concluded that the logical inverse must be true: that interstate takings prohibitions can be sustained if conceived as necessary to "a larger regulation of economic activity." See, e.g., GDF Realty, 326 F.3d at 640 ("ESA is an economic regulatory scheme; the regulation of intrastate takes of the Cave Species is an essential part of it. Therefore, Cave Species takes may be aggregated with all other ESA takes."). The bulk of the opinion is spent attempting to maneuver the ESA into this perceived safe harbor.

23. The court held that the case was governed by its prior decision in National Ass' $n$ of Home Builders v. Babbitt, 130 F.3d 1041 (D.C. Cir. 1997), but the court picked up on one rationale offered by that earlier panel-in Judge Henderson's concurrence-and made it the basis of the opinion. See Rancho Viejo, LLC v. Norton, 323 F.3d 1062, 1067 (D.C. Cir. 2003) (citing Nat'l Ass' $n$ of Home Builders, 130 F.3d at 1058 (Henderson, J., concurring)).

24. 323 F.3d at 1072. Judge Garland continued: "That regulated activity is Rancho Viejo's planned commercial development, not the arroyo toad that it threatens. The ESA does not purport to tell toads what they may or may not do." Id.

25. Id. (quoting United States v. Morrison, 529 U.S. 598, 611 (2000)) (alterations in original).

26. See id. at 1072-73.

27. Id. at 1077 (quoting Lopez, 514 U.S. at 558).

28. See id.

29. See id. at 1080 (Ginsburg, C.J., concurring). 
Both GDF Realty and Rancho Viejo are notable for their creativity, but only Rancho Viejo is equal to the task of beating back the challenge to the ESA. GDF Realty suffers from several serious defects. First, the court chose a method of Commerce Clause analysis-aggregating the effects of noneconomic activity-that the Supreme Court all but invalidated in Morrison. ${ }^{30}$ Second, the analysis was so speculative and vague that it could in principle justify nearly any congressional enactment. If Commerce Clause analysis were a matter of imagining whether a statute could hypothetically generate some economic value that might not exist absent the statute, it is hard to imagine any law that would fail the test. Certainly the Gun-Free School Zones Act and the Violence Against Women Act would pass, since improving safety reasonably might be thought to facilitate commercial activity. ${ }^{31}$ The Supreme Court is unlikely, however, to endorse any Commerce Clause formula that would undo the results of Lopez and Morrison.

Third, the Fifth Circuit's approach relied heavily on claims about Congress's motive for passing the ESA that are hard to substantiate. The court committed itself to justifying the ESA as economic regulation and to treating species as the object of regulation. Since the species in the case were not in any obvious way commercial objects, the court found it necessary to argue that Congress chose to regulate them for commercial ends. To do so, the court plunged into the legislative history of the Act and emerged brandishing a few sentences as evidence that Congress passed the ESA to enable the future commercial exploitation of protected species. ${ }^{32}$

30. The Morrison Court stated that "[w]hile we need not adopt a categorical rule against aggregating the effects of any noneconomic activity in order to decide these cases, thus far in our Nation's history our cases have upheld Commerce Clause regulation of intrastate activity only where that activity is economic in nature." 529 U.S. at 613 . Perhaps seeking a way around this language, the Fifth Circuit aggregated Cave Species takings together with all takings of endangered species, most of which are not confined to a single state. This move is unconvincing, though, as it has no precedent in Supreme Court case law, and it fails to introduce an economic element to the regulation. Cf. Jason Everett Goldberg, Comment, Substantial Activity and NonEconomic Commerce: Toward a New Theory of the Commerce Clause, 9 J.L. \& POL'Y 563, 571 (2001) (arguing that Morrison "seemingly differentiates between economic and non-economic activity and will not allow regulation of the latter even though there may be a rational basis to conclude that the activity substantially affects interstate commerce").

31. Indeed, the legislative history for the Violence Against Women Act contained findings to that effect. See, e.g., H.R. REP. NO. 103-711, at 385 (1994), reprinted in 1994 U.S.C.C.A.N. 1801, 1853-54.

32. See GDF Realty Invs., Ltd. v. Norton, 326 F.3d 622, 632 (5th Cir. 2003) (noting that "[genetic variations] are potential resources" (quoting ENDANGERED AND THREATENED SPECIES CONSERVATION ACT OF 1973, H.R. REP. NO. 93-412, at 5 (1973)) (alteration in original)). Not finding much support for the "species as resources" view in the record, the court later cited the legislative history of a different law, the Endangered Species Conservation Act of 1969. See id. at 639 (citing S. REP. NO. 91-526, at 1415 (1969)). 
Courts are usually suspicious of arguments about congressional intent that are grounded solely in legislative history, given the manipulability of the legislative record and the dubious precedential value of legislators' unenacted statements. ${ }^{33}$ The Fifth Circuit's arguments are especially suspect, as the court purported to divine not only how Congress intended the ESA to apply, but also the ultimate ends for which Congress wanted species protected.

Finally, to justify the ESA, the Fifth Circuit twisted its meaning, making its master narrative a story about economics. But the ESA is not about monetizing endangered species; it is about preserving them in their natural state. This characterization is not grounded in legislative history, but in the text and design of the statute. All the provisions of the Act are directed to the preservation of species without regard to their commercial possibilities. ${ }^{34}$ GDF Realty further speculates about why Congress would want to preserve species, but its answer is out of step with the design of the Act, which makes no reference to commercial ends. To analyze the ESA under the Commerce Clause by adding up what endangered species would fetch on the market is perverse, because the Act exists to protect threatened species from exploitation.

By comparison, Rancho Viejo offers a more promising approach to squaring the Endangered Species Act with Lopez and Morrison. By focusing on the residential development blocked by the statute, rather than the hypothetical market value of species, Rancho Viejo avoids GDF Realty's flight into speculation. The court hits on a Commerce Clause formula that is much easier to administer by pegging the Commerce Clause inquiry to something objective: the activity triggering the takings prohibition. Also, the Rancho Viejo approach stays on the good side of

33. For the classic contemporary critique of legislative history's use in statutory interpretation, see ANTONIN SCALIA, A MATTER OF INTERPRETATION: FEDERAL COURTS AND THE LAW (1997). While most judges would not agree with Justice Scalia's categorical rule against consulting legislative history, they are hesitant to accept claims about legislative intent drawn solely from the legislative record. See William N. Eskridge, Jr. \& Philip P. Frickey, Statutory Interpretation as Practical Reasoning, 42 STAN. L. REV. 321, 345-53 (1990).

34. See, e.g., ZYGMUNT J.B. Plater ET AL., ENVIRONMENTAL LAW AND POLICY: NATURE, LAW, AND SOCIETY 674 (2d ed. 1998) (observing that the ESA "made no distinction between species that have a commercial value or direct human utility and those that do not" but "gave legal value to an abstraction"). The ESA's preamble makes the noncommercial nature of this purpose clear: "The purposes of this chapter are to provide a means whereby the ecosystems upon which endangered species and threatened species depend may be conserved, [and] to provide a program for the conservation of such endangered species and threatened species ..." 16 U.S.C. $\S 1531$ (b) (2000). One of the Act's sponsors, Senator Harrison Williams, observed: "Most animals are worth very little in terms of dollars and cents. However, their esthetic value is great indeed. The pleasure of simply observing them ... is unmeasurable." Shannon Petersen, Comment, Congress and Charismatic Megafauna: A Legislative History of the Endangered Species Act, 29 ENVTL. L. 463, 479 (1999) (quoting 119 CONG. REC. 25,693 (1973) (statement of Sen. Williams)); see also id. at 467 (" $[\mathrm{M}]$ ost in Congress believed the Act to be a largely symbolic effort to protect charismatic megafauna representative of our national heritage, like bald eagles, bison, and grizzly bears."). 
Morrison by not looking for a substantial economic impact in the aggregation of noneconomic, intrastate activities. On the whole, Rancho Viejo has the virtues of clarity, objectivity, and consistency with the dictates of Lopez and Morrison.

At the same time, Rancho Viejo has problems of its own. The ESA is not a regulation of commercial development qua commercial development: It is a regulation of anything and everything that would take an endangered species. In fact, GDF Realty makes this very point in rejecting the analysis Rancho Viejo adopts: "True, the effect of regulation of ESA takes may be to prohibit such development in some circumstances. But, Congress, through ESA, is not directly regulating commercial development." 35 It misrepresents the statute to argue that it is essentially a regulation of commercial development, and that noncommercial activities subject to it are only "individual instances" of "de minimis character." 36 The text of the statute proves the point: Of the ten meanings given for "take" in the statute, at least seven are most strongly associated with the activities of outdoorsmen. $^{37}$ It seems that the lone hunter, not the bulldozer, is the prototypical "taker," at least from the perspective of statutory design. ${ }^{38}$ The ESA's regulation of interstate commerce is merely circumstantial: The statute regulates commerce when that happens to be what threatens endangered species.

Thus, while Rancho Viejo is on solid ground when it upholds the ESA as applied to commercial activities that threaten species, the broader claim that it is justified in all its applications rests on a dubious characterization of the statute. Chief Judge Ginsburg's more modest position-that the takings prohibition is permissible insofar as the threat comes from activities with a substantial effect on interstate commerce-is easier to justify under Lopez and Morrison. But even if this position satisfies Lopez and Morrison, it is unsatisfactory as a matter of policy. Judge Garland is right that "the ESA

35. GDF Realty, 326 F.3d at 634.

36. Rancho Viejo, LLC v. Norton, 323 F.3d 1062, 1077 (D.C. Cir. 2003). The court relied on United States v. Lopez, 514 U.S. 549, 558 (1995), and Hodel v. Indiana, 452 U.S. 314, 329 n.17 (1981), for the proposition that not every facet of a statute must be related to commerce if the statute as a whole is.

37. Those seven meanings are "pursue," "hunt," "shoot," "wound," "kill," "trap," and "capture." 16 U.S.C. $§ 1532(19)$. For the complete list of meanings, see supra note 16. This list reflects Congress's understanding of the nature of the threats to species; the ESA's Senate sponsor, Senator Williams, "stated that overhunting was 'undoubtedly' the 'major reason' for species extinction." Petersen, supra note 34, at 482 (quoting Endangered Species Act of 1973: Hearings on S. 1592 and S. 1983 Before the Subcomm. on Env't of the Senate Comm. on Commerce, 93d Cong. 114 (1973) (statement of Sen. Williams)).

38. According to Secretary of the Interior Gale Norton, most of the activities that currently run afoul of the ESA's takings prohibition are commercial or economic in nature. See Rancho Viejo, $323 \mathrm{~F} .3 \mathrm{~d}$ at 1078 . Even if this is true, it does not justify treating development as the core object of the ESA, because that is a question that must be answered with reference to the statute's design, not its pattern of enforcement. 
represents a national response to a specific problem of 'truly national' concern," 39 and that limiting its scope to takings that are commercial in nature would undermine it. Because species are interdependent and their habitats stretch across state lines, a program of species preservation needs to be comprehensive and national in scope to be effective. ${ }^{40}$ It is arbitrary to protect endangered plants or animals if they are threatened by construction of a shopping center, but not by a homeowner putting in a pond, and to apply the statute in this patchwork manner would hobble the ESA and trivialize its purposes.

Ultimately, the problems with Rancho Viejo can be laid at the feet of Lopez and Morrison. In order to square the Endangered Species Act with those cases, the D.C. Circuit was forced to foreground the Act's impact on commerce, even though this impact is only incidental to the statute's design. But this treatment of the ESA as economic regulation is not really convincing, and the Act's application to noncommercial takings rests on shaky ground. Before Lopez and Morrison, courts had only to show a substantial impact on commerce to justify statutes. To do the same now they must search for some economic nexus, however peripheral, and present it as the statute's core concern. The harm here is not only that some statutes may be struck down, but also that courts cannot uphold their responsibility to say what the law is when their statutory interpretations stretch credulity.

Lopez and Morrison hit on an important truth: The Commerce Clause must impose some limits on Congress's power to legislate. Despite the best efforts of the D.C. Circuit, however, the Endangered Species Act-a national solution to a national problem-finds only unsteady support in the Supreme Court's new Commerce Clause jurisprudence. The Commerce Clause must mean something-but GDF Realty and Rancho Viejo show why Lopez and Morrison are poor guides to its meaning.

-Jud Mathews

39. Id. at 1078-79.

40. See ENDANGEREd AND THREATENEd SPECIES CONSERVATION ACt OF 1973, H.R. REP. No. 93-412, at 7 (1973) (noting that "protection of endangered species is not a matter that can be handled in the absence of coherent national and international policies: the result of a series of unconnected and disorganized policies and programs by various states might well be confusion compounded"). 